\title{
Religion in Early Modern Southeast Asia: Synthesising Global and Local
}

ANTHONY REID

The conversion of Southeast Asia to its three modern global faiths (Islam, Christianity and Theravada Buddhism) is usually told in terms of foreign arrivals, interventions and successes, or (by reaction) of a relatively seamless gradualism Ricklefs' "Six Centuries of Islamization" (1979). For those mainly concerned with contemporary phenomena, the categories "traditional" or "pre-colonia" are so remote as to defy further subdivision. The interaction between global and local is of course a never-ending one, but it is possible and indeed important to discern periods when global ideas appeared particularly compelling to the Southeast Asians in contact with them, and others when the Zeitgeist appeared to be a reaction against alien forms and search for synthesis. Sheldon Pollock (2006) has suggestively used the term cosmopolis for the former, referring to the "Sanskrit cosmopolis" of the first centuries CE, implying "vernacularisation" as its opposite. Ronit Ricci (2011) more recently applied the cosmopolis term to Muslim Asia, though not in the diachronic sense I have in mind. I want here to explain why I think the diachrony between these two processes is particularly critical in Early Modern Southeast Asia. Since I have adopted different formulations of these two phases since first launching the terms "Age of Commerce" and "religious revolution" two decades ago, it may help to set them out below. 


\begin{tabular}{|l|l|}
\hline c.1490-1650 & c.1650-1820 \\
\hline long 16th century & long 18th century \\
\hline $\begin{array}{l}\text { Age of Commerce (Reid } \\
\text { 1988) }\end{array}$ & $\begin{array}{l}\text { Last Stand of Asian Autonomy } \\
\text { (Reid 1997) }\end{array}$ \\
\hline $\begin{array}{l}\text { "religious revolution" (Reid } \\
\text { 1993) }\end{array}$ & popularisation, consolidation \\
\hline "cosmopolis" & "vernacularising" \\
\hline Early Modern I & Early Modern II \\
\hline
\end{tabular}

This alternation helps to explain the hard lines that emerged in the first phase between lowland and highland, scriptural and animist, and state and non-state, with the second of each of these dyads developing unprecedented resistance to incorporation into the first. It also helps to locate in time the emergence of what we think of as popular religious syncretism, primarily in the long 18th century.

\section{Long 16th Century - “Religious revolution”}

The rapid expansion of commerce through much of maritime Asia in the long 16th century accompanied a new universalism of ideas, a quest for cosmopolis akin to that which had spread Buddhist universalism in the previous millennium. But this was a new universalism that ushered in modernity, or what has been aptly called the early modern era in world history, in which nobody could escape the collision of rival universalisms. Elsewhere I have labelled this period a "religious revolution" for Southeast Asians, which established the ways in which they would identify themselves as individually responsible members of universal cultures (Reid 1993: chap. 3). Each of the new scriptural religions brought a sense of its own core and its own boundaries, conscious of being in competition with other universalisms. While the impetus that drove Southeast Asians to adopt such religions was similar - a commercial, cosmopolitan, competitive environment that shook the foundations of older local beliefs - embracing these religions put them on paths which would ultimately diverge. Unlike the changes brought by Buddha and Shiva, which created further patterns of interaction across the region and beyond, the new universalisms divided the region into five 
modes of modernity. Over the following centuries the Islamised south, the Theravada Buddhist north, the Christianised east, and Confucianised Viet culture grew gradually more distinct from each other and from the fifth mode, the remaining adherents of an older Southeast Asian religious pattern.

This last-mentioned category was the most fundamental layer of Southeast Asian belief. At the outset of this revolution it may have been almost universal, coexisting naturally with both the popular Mahayana Buddhism of wet-rice growing communities, and the Shiva cults of ambitious kings. In highland areas, among swidden cultivators and hunter-gatherers, and in all the islands to the east of Bali, it was virtually uncontested until the "religious revolution" of the long 16th century. That revolution introduced in varying degrees the four scriptural universalisms, each concerned with uniformity and with boundaries against each other and against the Southeast Asian pattern. Nevertheless the latter survived everywhere, as it does today, not only in holdouts against the new such as the Dayak, Toraja, Ifugao, Karen and Hmong, but in partnerships suffusing the scripturalisms and supplying what they lacked.

\section{Southeast Asian Religion}

Because of problems associated with use of terms such as animism and shamanism I have chosen to label this older pattern simply "Southeast Asian" religion, though that too risks exaggerating the differences from some ideas that had nearuniversal currency. Certainly there is no geographical boundary to this mental universe. Some of the key features of the pattern arise from its contrast with modern "religion", a concept that took hold later in Southeast Asia than in Europe, China and India. The most reliable descriptions of the system from the age of commerce itself come from Christian missionaries, especially in the Philippines, who needed to understand what they were up against, but the more systematic work of modern ethnographers in many areas is also very helpful.

The spiritual realm was immanent and pervasive; inseparable from the practical or everyday. European missionaries found the system crassly materialist, interested only in gain, but they quickly realised that if they could not cure ailments, safeguard life passages and make the rains come on time, they could not compete with traditional rituals. Spirits were everywhere there was power, and keeping those spirits content and well-disposed was the business of the specialist. A distinction was widespread between the dangerously mobile spirit or soulessence of living individuals (Malay semangat; Thai khwan, Burmese leikpya), which needed to be ritually brought back or re-concentrated in the body at vari- 
ous life crises, and the myriad spirits (Thai phii, Burmese nat) of nature and of deceased humans that governed the inhabited world. Austronesian terms for the latter are too numerous to record, though cognates of anita (anitu, hantu) are widespread, and Arabic-derived roh has become a generalised term in Malay. The dead continued to influence the living for better or worse. Illness in the living might be attributed to inadequate or incorrect death rituals for a relative recently passed on, and health and prosperity similarly attributed to appropriate manipulation of the powerful spirits of ancestors, heroes, or powerful animals. Even the most important agricultural spirit, that residing in the rice plant, was often humanised as originating from a virtuous maiden sacrificed for the good of humanity.

Among all the panoply of rituals for every life passage, those for death were the most elaborate. An acute 17th century observer noted how Southeast Asians, "do not only believe that they may be helpful to the dead...; they think also that the dead have the power of tormenting and succouring the living; and from hence comes their care and magnificence in funerals; for it is only in this that they are magnificent" (La Loubère 1969[1691]: 121). No feast was more important, and since feasts were the only occasion for meat-eating, the sacrifice of a pig, chicken or buffalo was intimately linked to the ritual. Dancing and consumption of alcohol was often part of such feasts, to the horror of moralists of all the scriptural religions, because it was necessary to reaffirm life amidst death, and to assure the deceased that legions were gathered to celebrate his or her name.

Although I am describing a "system" of religious belief, by contrast with the modern and scriptural, contemporaries were bewildered by its diversity. A Dutch investigation of beliefs in the Ambonese area noted that "the informants differed so widely that it was impossible to describe the system" (Knaap 1987: 71), while modern ethnographers have similarly insisted on the extraordinary abundance of spirits particular to each village or even each household. There was also a necessary experimentalism amidst this diversity. Those whose enterprises prospered and whose crops and children were abundant were assumed to have adopted the right rituals, and others would seek to find the ritual formula kept secret by the beneficiary. Hence when Muslims and Christians appeared among them who appeared successful in both trade and warfare, their ritual secrets were also keenly sought. Some decided they should spurn pork simply because this seemed the key Muslim formula, while the holy water used by Catholics in the sacraments was sought after as a healing remedy. This fundamental openness in the system made it a ready field for "conversion", though at least initially without abandoning the assumptions of the old system. 
One striking difference between the old and new religious systems was in their gendering. Southeast Asian religion was balanced and dualistic, with the female gods of the earth (including rice), moon and the underworld matching the male ones of the sky, iron (which ploughs the earth), sun and upperworld. Women were indispensable in ritual, as healers and mediators with the spirits. In some areas like South Sulawesi the particular potency of the male-female mix ensured that the most powerful shamans were of a third gender, the transsexual bissu. By contrast scriptural religions (including the earlier Shaivite and Buddhist ones) were brought to the region by exclusively male specialists with developed concepts of the maleness of their gods and prophets, of a celibate male ascetic ideal, and of female impurity and ritual pollution. Not surprisingly, it was men who most readily adopted the new faiths, often relegating the old rituals to the sphere of women's business, however necessary they may still have been to ensure fertility and health. In the Philippines the missionaries of the celibate religious orders found that "the priestesses whom they call babaylanas made strong resistance and war against them" (Reid 1993: 162). Whereas in China and elsewhere the Christian stress on lifetime monogamy attracted women in particular, this was a mixed blessing for those accustomed to the widespread Southeast Asian pattern of fidelity within marriage but relatively easy divorce and remarriage. One Visayan lady told a missionary that "it was a hard thing if unhappy with one's husband one could not leave him, as was the custom among them" (Chirino 1969[1604]: 313).

\section{Rival UNIVERSALISMS}

The initial crusading zeal of the Portuguese had not involved great interest in preaching or proselytising, and their early converts were chiefly their wives, children or close allies for whom this was the mark of identity. Their global conflict with a Turkish-led Islamic world, however, became caught up in the European reformation and counter-reformation, and thereby with early modernity. Although the Catholic Counterreformation associated with the Council of Trent (1545-1563) was stimulated largely by the Protestant challenge in Germany, its most faithful agents, the Jesuits, saw their great mission as to the east. Ignatius Loyola had made a pilgrimage to Turkish-ruled Jerusalem before establishing the Society of Jesus in 1534 (approved by the Pope in 1540), and always saw Asia as the greatest challenge for Christendom. His closest friend Francis Xavier was sent to Asia on a Portuguese ship at the first opportunity, and wasted no time in translating texts and preaching to every Asian society he could. Little 
more than two of his ten Asian years were in Southeast Asia (1545-1547), but he transformed the Christian approach by preaching and teaching in Malay and baptising thousands, notably in Melaka, Ambon and the other islands of Maluku. Before moving on to more ambitious targets in Japan and China, he introduced Jesuit methods and personnel to Southeast Asia, and inspired the older preaching orders, Augustinian, Franciscan and Dominican, to adopt a similar rigour.

This serious missionary impetus had its effect also on enclaves such as Melaka - Portugal's primary Southeast Asian base. Portuguese who were living with Asians were pressured to Christianise and marry them. The women in turn had to adopt Portuguese norms of decency in dress. At a 1532 census of Melaka only 75 Christian women were enumerated, whereas there were thousands by the end of the century. On the other hand this increasing Christianisation of the Portuguese presence further reduced the plurality which had been such a mark of the Asian ports. Since the 1511 conquest Portuguese Melaka had attempted to govern its non-Christian traders through a former Malay official, the bendahara, who faced terrible problems mediating between Portuguese and Asians. The conversion of the last bendahara to Christianity in 1564 marked the end of the influence of the once-powerful Indian communities in Melaka.

When Philip II of Spain, the mightiest Christian monarch of the day, decided that Spain should establish a permanent presence in Asia, it was in a wholly different reformist mind-set than the Portuguese crusaders, or indeed the conquistadors of the Spanish Americas a century earlier. The expedition Philip commanded to sail from Mexico to the Philippines (already so named in his honour) in 1564 was motivated partly by Southeast Asian spices, but "the most important thing His Majesty desires is the spread of our Holy Catholic Faith and the salvation of the souls of those infidels," as Legazpi was instructed (Zaide 1990: 408). ${ }^{1}$ Its command had been entrusted to Fr Andres Urdaneta, navigator turned Augustinian priest, but when he refused this he became instead the spiritual guide of the mission alongside Miguel de Legazpi as military commander. Six Augustinian priests went out on this mission, which began the colonisation of the Philippines at Cebu in 1565, transferring the centre to Manila in 1570. The number of missionary priests rose to 13 by 1576,94 by 1586 and 267 by 1594 (Phelan 1959: 56). This was more than tenfold the numbers the Portuguese sent to the rest of Southeast Asia. They translated and printed devotional texts in Tagalog and Visayan, and by 1650 had accomplished the Christianisation of Luzon and the Visayas, except for the highland redoubts of the resisters.

1 Documentary Sources of Philippine History, Vol.I, Metro Manila: National Book Store. The instructions to Legazpi by the Royal Audiencia of Mexico, 1 Sept. 1564, are at pp.397-410. 
Though peaceful by the standards of Latin America, the Spanish presence in Manila was also influenced by the global struggle referred to above. Manila was a useful base for missions to Cambodia, Vietnam, China and Japan. Alarmed at the sending of Islamic teachers to Mindanao by Ternate and Brunei, Spanish Manila sent expeditions to Mindanao and Sulu and in 1578 succeeded in sacking Brunei and curbing that city's role as a hub of trade and Islamisation for the Philippines. Henceforth the sultanates based in the island of Sulu and the Pulangi river basin of Magindanao would be the primary political upholders of Islam and of resistance to the Spanish in the Philippines. The greatest strength of both these polities was their pluralism or oligarchy, which made it impossible for the Spanish to turn their military superiority into permanent influence through a pliant king. Only the long reign of Sultan Qudrat in Magindanao (c.1619-1671) produced a strong political centre for Islam in this period, partly thanks to Dutch commercial support.

Some of the reasons why Filipinos embraced Christianity so rapidly were similar to those that persuaded others to embrace Islam in the same period. The experimental nature of Southeast Asian religion tended to see success in warfare, well-being and trade as indicative of correct ritual practice, so that the success of Muslims and Christians in these areas inspired emulation. The rapid economic expansion of Southeast Asia's long 16th Century pulled many away from their local agricultural roots, and made a portable, universal religious code attractive. The scriptural religions also countered the pervasive and terrifying power of malign spirits with a relatively predictable, rationalised moral code. The abundant Spanish missionary accounts of the conversion of the Philippines are rife with descriptions of the "demons" that terrorised the inhabitants until conquered by the power of the cross and the sacraments (Reid 1993: 150-161).

If the motives for the "religious revolution" of early modernity were similar, the modalities of Muslim and Christian proselytists were strikingly different. Muslim traders and scholars married locally, even if already married at home, and their families provided a built-in mechanism of localisation. But the counterreformation Catholic Church was determined to enforce the discipline of a celibate clergy as the sole mediator of sacramental power. This tended to keep the church European in leadership and orthodox in faith in its early stages. The clergy's monopoly of spiritual power was particularly unpalatable for Southeast Asian rulers, whose main source of power in the old order was as mediators with the cosmic order. The Portuguese made many attempts to baptise kings as Christians, but all failed once it became clear that their conversion destroyed their former spiritual potency without giving them access to the supernatural power of the Christians. By contrast Muslim and Theravada Buddhist rulers found numer- 
ous ways to manipulate the new religion to enhance their eminence. Arabic terms such as dawla (the state) and wahy (the divine inspiration revealed in the Prophet) were used to give an Islamic legitimation to the supernatural potency uniquely claimed by rulers, in Malay (daulat) and Javanese (wahyu) respectively. The newly potent gunpowder kings, moreover, were able to use the new externally validated religions to override the highly plural contractualism of many Southeast Asian societies (Reid 1993: 169-173).

The long 16th century brought early modernity to Southeast Asia in the sense that all elites became aware of the competing universalisms of Islam, Christianity and Buddhism, and the need to choose among them. If the Muslim-Christian conflict had begun with brutal raiding and warfare in the early 1500 s, by the latter part of that century it had acquired intellectual and spiritual dimensions, as both scripturalisms were creatively translated into vernaculars. Muslim literary creativity was particularly striking in the century $1580-1680$, effectively creating what we now call classical Malay literature.

The contest between Habsburgh-led Catholic Christendom and Ottoman-led Sunni Islam ended quickly in the 17th century. The most implacable enemies of Catholic Portuguese after 1600 were not Muslims but Protestant Dutch, who initially sought Muslim powers like Aceh and Banten as allies. Dutch and English success in shipping spices and pepper around Africa completely eclipsed the Muslim trade route through the Red Sea by the 1630s. Together with the slow decline of Ottoman (and Spanish) power, this broke the direct link between Southeast Asian and Middle Eastern Muslims. The 17th century economic crisis of which this severance was part (Reid 1993) inaugurated the new phase of vernacularisation (below).

\section{Pluralities, Religious boundaries AND the "HIGHLAND SAVAGE"}

In the evolution of Southeast Asian pluralities, the religious revolution of the long 16th century was a major turning point. It might be said of this region, as of others, that homogeneities were eventually imposed on the natural diversity of spatially separate peoples by the twin forces of scriptural religion and bureaucratic states. These forces were slower in Southeast Asia than elsewhere to overcome the environmental barriers to integration, which retained a high degree of pluralism up to very recent times. In the "age of commerce", however, the competing universalisms just discussed confirmed some of the enduring boundaries 
in the region, not only between Muslim, Buddhist, Christian and Confucian, but also between "civilised" lowlanders and "savage" highlanders.

The oldest and most enduring distinction was that between modes of production: hunter-gatherers, forest and sea exploiters, shifting cultivators, and settled wet-rice growers. All these remained options in Southeast Asia, where tropical forests continued to dominate the landscape until the twentieth century. Each mode had its advantages in relation to particular environments, and there are myriad examples from past and present of combining modes and shifting between them. Only settled rice-growers provided what Scott (2009: 73) calls a "state-accessible product", compatible with state control and exploitation, but the open frontier ensured that most agriculturalists could escape oppressive state control by moving further into the forest.

Traders, missionaries and soldiers brought the new universalisms to impact with this ecological diversity in the long 16th century. Let me focus here on the boundaries created by two crucial and interrelated factors - the growing reach of states and the behavioural boundaries of the scriptural religions.

The state factor was most marked outside the Sinic world in the Philippines, where Spanish control had expanded throughout the lowlands of Luzon and the Visayas by 1650, in tandem with Christianity. The limits to Spanish control were logistic. With a very small number of soldiers, they could not sustain supply lines for an extended campaign in the hills far from Manila, against significant resistance. Those who resisted therefore tended to focus in the Cordillera that runs down the middle of Luzon. Even though the islands' most valuable asset from a Spanish viewpoint, gold, was chiefly in the Cordillera, the early Spanish campaigns to reach it were unsuccessful, and they gave up trying by the mid17th century. The most widespread revolt against Spanish control occurred in northern areas of Ilocos and Pampanga in 1660-1661. Some highlanders participated, and the unreconciled holdouts naturally retreated to join them in the hills when it was suppressed. Pre-Spanish highlanders were already less literate, less hierarchic, and less inclined to permanent-field rice agriculture than the lowlanders, but these distinctions became far more marked with Spanish control of the lowlands. Spanish officials and priests suppressed petty warfare, head-hunting and elaborate death-feasts in the lowlands, and established Iberian Catholic patterns of marriage and dress, as well as homogenising the main language groups through the introduction of printing. The Cordillera remained diverse in language and religious practice, and the continuation of low-level warfare and headtaking made it seem increasingly wild and dangerous to Spanish and Chinese, and eventually to the lowlanders themselves. 
Recent advances in dating the spectacular rice terraces built by the Ifugao in the Cordillera suggest that they began to be built subsequent to Spanish control of the Cagayan valley floor. The most probable explanation for the sequence of carbon dates obtained is that wet-rice agriculturalists from that rice-bowl of Luzon retreated under Spanish pressure rather than surrendering their religious and social habits. Accustomed to intensive rice-growing in permanent flooded fields, they developed the characteristic rice terraces in the hills of the region, rather than adopt the shifting cultivation of long-term hill-dwellers (Acabado 2009). If this is the explanation for Ifugao rice-terraces, a similar process probably gave rise to the irrigated terraces of the upland Toba and Karo Bataks in northern Sumatra, Torajans in Sulawesi and even Balinese. But here the factor pushing irrigated rice-growers up into the highlands would have been Islamic pressure rather than Christian.

To begin with Batak, before the $16^{\text {th }}$ century, this term appears as a place or polity, presumably representing the point on the coast where foreign traders encountered the then majority peoples of northern Sumatra. By 1515 the Portuguese understood the rulers of this place and of nearby Aru (likely ancestor of Karo-Batak) to be Muslims, but evidently of so different or superficial a type as not to be accepted as Muslim at all in the polarised atmosphere that followed the rise of Aceh and its bitter conflict with the Portuguese. Bata and Aru sided with the Portuguese in that conflict, and became early victims of Aceh expansion. Mendes Pinto (1989[1578]: 20-49) ${ }^{2}$ tells a tragic story of a militant Aceh sultan, supported by Turks and Gujaratis, offering only Islam or death to his Batak rival despite the latter's attempts at accommodation. When his sons were murdered, his troops defeated and the Portuguese failed to help him, the embittered "king" moved further up into the hills and abandoned his commercial links with the outside world. This appears to mark a turning point, after which the term Batak was used for uplanders defined by their resistance to Islam and the coastal states that represented it, rather than by any particular language or location. Barros (1973[1563]: Dec. III: 509) could later report that Sumatra was "inhabited by two kinds of people", indigenous animists and Muslims derived from foreign traders, who took over the coastal areas over the previous century and a half and created Islamic states. "The heathens, leaving the coast, took refuge in the interior of the island and live there today. Those who live in the part of the island

2 Though the reference is to the most recent English translation, by Rebecca Catz, there is a later scholarly edition in Portuguese with extensive English footnotes: Fernão Mendes Pinto and the Peregrinação: Studies, Restored Portuguese Text, Notes and Indexes, Directed by Jorge Santos Alves (Lisbon: Fundação Oriente, 2010), Vol. III. 
facing Malaca are called Batas. They are the most savage and warlike people in the whole world; they eat human flesh."

In the less polarised "long $18^{\text {th }}$ century" described below many did gradually assimilate to Islam, and the Gayo in the interior of today's Aceh Province also accepted Aceh suzerainty in the milder form it was later presented. But the memory of this violent confrontation ensured that there was active resistance as well as simple isolation among uplanders. The chronicles of Muslim Barus, a key Batak outlet to the sea, portray its founding king-hero touring the Batak areas before establishing his kingdom on the coast. Each community asked him to stay as their king, but when he then asked them to become Muslim they replied apologetically, "We do not want to enter Islam. Whatever else you order we will obey" (Drakard 1990: 75-80). Symbiosis between uplanders and the coastal portruler was acknowledged in this foundation myth, but the dividing line between them was clear. It was epitomised in practical terms by the continued importance of pigs in the feasting of Bataks and most other non-Muslim uplanders. When Minahassan missionary teachers, and Chinese traders, penetrated into Batak areas for the first time they were also considered Batak, since they ate pork.

The Batak story has parallels elsewhere, wherever rapid military expansion by aggressive Muslim states in this period provoked a new sense of different highland identity. Nearby, the seemingly primeval megalithic culture of Nias is now thought to have been inaugurated only in the 17 th century. Oral genealogies and carbon dates for the remarkable megaliths with which the Niha honoured their ancestors in their hilltop villages agree on this dating (Bonatz 2007: 4). The Toraja of Sulawesi are another such case. Their language, culture and ritual are very close to those of the neighbouring Bugis of the lowland. Their freedom from coastal states and from Islam appears to have been a deliberate choice, probably also involving the flight to defensible highlands to avoid unprecedented pressure to submit to alien political and religious forms. The Toraja memory as still chanted at feasts in modern times is of an alliance of those who "held back the mountain of Bone" (untulak buntuna Bone), and swore an oath of resistance. This is usually associated with the most powerful of Bone's Kings, Arung Palakka, who with Dutch help liberated the Bugis from Makassar domination in 1669 and is believed to have carried his domination into the highlands in the 1680s. Those who joined the resistance oath are remembered as ideal ancestors who became "people of the same level or destiny, people of the same dream" (to pada tindo, to misa' pangimpi). In the chants it is remembered that $\mathrm{X}$ from village $\mathrm{Y}$ "likewise held back the mountain of Bone in the days gone by. He too. And the harvest of the earth was abundant at that time, and human beings multiplied" (Waterson 1997: 73-76). This memory of an agricultural golden age sug- 
gests that the seventeenth century was the time when the Toraja began to carve their hillsides in beautiful terraces of irrigated rice, just as did the Ifugao.

An analogy in Java to the Islam-induced upland statelessness of the Batak and Toraja may be the Sundanese of West Java, who withdrew to the highlands in the $16^{\text {th }}$ century but accepted Islam in the syncretising long $18^{\text {th }}$ century. This is a complex issue that must be explored elsewhere. In the Javanese-speaking area in the eastern two thirds of the island, however, the synthesis achieved by Sultan Agung (r.1613-1646) succeeded in absorbing even uplanders rather than forcing a hard choice upon them. This achievement needs to be compared with that of Sultan Akbar and other Muslim rulers of India in the same period, who never could achieve the same consensus either through compromise or coercion. But the literate and political elites of Java moved east in face of the attacks from Muslim Demak in the polarised 16th Century. Pasuruan and Balambangan in the furthermost east of Java held out for some time, but in the 17th century only Bali remained as the bastion of an older Hindu-Buddhist civilisation. Its high population and elaborate irrigated-rice system undoubtedly owe something to migrations from Java at this time. Though differing from highlanders in their hierarchic social system and elaborate literary culture, and in being defended by water rather than mountains, Balinese also encouraged their reputation for ferocity, for they knew the dangers the Muslim states posed to them long before they knew the potential danger of Europeans.

Mainland Southeast Asians followed a different historical rhythm, though with some of the same long-term results. At moments of neo-Confucian success and assertiveness among the Viet, in the 15th and early 19th centuries and to a lesser extent the 17th, state attempts to enforce Confucian norms bureaucratically did create reaction and rejection in the highlands. But in the remainder of the Mainland Theravada Buddhism expanded through the charismatic power of its sacred centres and its sangha, with little sense of boundary against the unbeliever or savage. There were certainly aggressive campaigners against the old spirit religion in the 16th century, of whom the Burmese conqueror Bayinnaung was paramount. The chronicles show him building Buddhist temples throughout the areas of Upper Burma that he conquered, unifying their diverse religious calendars with his own, and outlawing human and animal sacrifices. Yet he only destroyed shrines to the spirits (nat) if he deemed they had failed to aid him in his campaigns, and belief in them remained universal in Burma until the twentieth century. Earlier (1527), Luang Prabang had destroyed its great shrine to the local spirit at the meeting of its rivers, and built there a Buddhist pagoda, yet a Portuguese source a little later described a great diversity of cults and of blood sacrifices still thriving there (Reid 1993: 193-194). 
The upland communities that survived and developed a separate identity from lowlanders in the mainland did so chiefly by pragmatically sending some form of symbolic tribute to the lowlanders with whom they traded, invoking their intervention only when it seemed necessary to fend off rival lowland centres. Until the 19th century the Jarai in the hills between Khmer and Viet territory exchanged gifts with each King of Cambodia, in acknowledgement of a symbiosis symbolised by their possession of a sword inherited from ancient Cham rulers, of which the Khmer held only the scabbard. But in return for being acknowledged as suzerain, the Cambodian king sent presents of far greater value than he received - not unlike the rulers of China.

The people now known as Karen occupy the hills between two lowland Theravada cultures - the Myanma and Mon in the deltas of the Irrawaddy and Salween, and the lowland Thai of the Chaophraya basin. They were typically diverse stateless communities trading their forest products and hill crops to the lowlands, and often content to see it interpreted as tribute. Although as usual their history is poorly known, in the late 18th century the missionary bishop Sangermano (1966[1833]: 44) singled them out in his account of Burma: "although residing in the midst of the Burmese and Peguans, they not only retain their own language, but even in their dress, houses, and everything else are distinguished from them; and what is more remarkable, they have a different religion". This suggests that despite their great internal diversity, many Karen uplanders had consciously begun to distinguish themselves from lowlanders. At least since the mid-19th century an origin myth was shared among them, whereby the founding ancestor entrusted with the book of knowledge by the creator-god had lost it through carelessness, and thereby left the Karen without writing as their neighbours forged ahead. Baptist missionaries in the 1830s found the Karen exceptionally receptive, believing that their just deserts as elder brother to the Burmans were being returned through the new writing the missionaries brought.

\section{Long 18th Century consolidations}

In the 17 th century there was a change of direction, as long-distance trade and foreign involvement began to yield more dangers than opportunities. Despite the different political results of this shift in different parts of the region, all experienced a vernacularising response in the long $18^{\text {th }}$ Century, following the cosmopolitanism of the long $16^{\text {th }}$. In the new period cultural identities consolidated in their different directions, enabling us for the first time to speak of Myanma, 
Thai, Vietnamese, Cambodian, Acehnese, Bugis, Javanese and Balinese as coherent identities, more enduring than dynasties that claimed to rule them. If the gunpowder empires had brought together diverse peoples sheltering under a common power centre, their successors focussed their primary ambitions on religion and culture, seeking to make up as exemplary centres what the gunpowder empires had lost in military power.

In the long 18th century the societies in question developed literary cultures, unifying religious syntheses, and histories that celebrated the warlike conquerors of the gunpowder age even as their political heritage was rejected or lost. Their economies became less dependent on the vagaries of the international market, but more monetised and marketised internally, as the cities shifted their roles towards internal rather than international exchange.

\section{RELIGIOUS SYNCRETISM AND LOCALISATION}

It is in the nature of universal scripturalisms to be subject to recurrent waves of reform legitimated from external sources - the original texts or the authority of a foreign centre imagined as purer. This type of polarising reformism was prominent during the long 16th century age of commerce, as we have seen, and periodically revived thereafter until peaking again as the world became more directly unified during the high modernism of the long twentieth century. In between these two phases, however, the second, self-strengthening phase of the Early Modern witnessed some remarkable achievements of synthesis and syncretisation, helping to unify societies that had been polarised by external influence. The gunpowder kings (including Spanish governors of Manila) had often enforced universal religion to justify their expansion, but in this second phase religious networks were more autonomous, and rulers needed to honour them in order to share in their charisma.

The survival of Southeast Asian religion, and its understated but effective incorporation into the religious syntheses of the long 18th century, has a key gendered dimension. Women had such a lowly place in all the three scriptural religions that made gains in the Age of Commerce, that it is difficult to understand how they could have been accepted in Southeast Asian societies distinguished by the economic autonomy of women and their centrality in ritual life. We know that female shamans were among the strongest defenders of the old religion in the Philippines and other parts of the island world. But the syntheses that took hold in the longer run allowed women to continue attending to key concerns of healing, childbirth and agricultural fertility by ritually manipulating spirits. The 
male specialists of the new religions could be avoided when stern, but asked to add their blessing when accomodating. Female ancestral spirits and rice goddesses remained influential figures, and sometimes the tombs of the wives of Islamic saints received the most offerings from women seeking safe childbirth. When sternly male Viet Confucianism took over southern areas where the Cham goddess Po Nagar was previously worshipped, it was obliged to allow Confucianised goddesses to take her place as healer and protector. A British visitor to southern Vietnam in the early 1800 s was struck by the number of "priestesses" (spirit-mediums) he encountered (Wheeler 2006: 184-187).

Since Islam demonstrated the vernacularising trend most dramatically, let us begin there.

\section{Islam}

The polarisation described above reached a peak in the reign of Sultan Iskandar Thani (Iskandar II) of Aceh (1636-1641). He was a devout Pahang-born Malay prince, brought captive to Aceh after the conquest of his homeland, and married to the daughter of Aceh's tyrannical sun-king, Iskandar Muda. That king had imposed Islam according to his own tastes, which included the mystic monism of Hamzah Fansuri and Syams al-din al-Samatrani (d.1630). The second Iskandar, his son-in-law, however, sought legitimacy through patronising foreign ulama who identified themselves with the universal orthodoxy of the Persian theologian al-Ghazali (1058-1111). Chief among them was the prolific Gujarati-born theologian Nurul-din al-Raniri, a stern upholder of what he held to be the literal demands of the shari'a.

Under Raniri's influence Sultan Iskandar Thani enforced a narrow view of shari'a even at the expense of Aceh's harmony and its cosmopolitan prosperity. Chinese traders were excluded from Aceh because of their pork-eating habits, and a Portuguese peace mission was offered the alternative of conversion to Islam or execution. He had the books of Hamzah Fansuri and al-Samatrani burned in front of the great mosque, and invoked the Islamic murtad (apostasy) laws to have executed those who refused to renounce the proscribed views.

These divisive interpretations were rejected after the death of Iskandar Thani in 1641. The commercial elite that dominated the city's commerce had been terrorised by the first Iskandar's absolutism and preference for foreigners, but shocked when Raniri and the second Iskandar proved both cruel and bad for business. They hoped to correct both excesses by placing a woman on the throne, daughter of one Iskandar and widow of the other, defying Islamic strictures against female rule. The results were so satisfactory that they enthroned three 
subsequent women, covering the period 1641-1699. We might ask whether the conventional disbarring of women from exercising religious authority was seen as an advantage, preventing the execution of divisive measures such as those advanced by Al-Raniri. It may have been a means of legitimating the pluralism essential to stable commerce by default of a sole religious authority. Under the queens the Chinese returned, a Franciscan mission served the small Christian community, and Aceh became the only Southeast Asian maritime state to withstand the pressure of the Dutch Company.

Hearing of the death of Raniri's protector, a Minangkabau disciple of the executed sheikh, Sayf al-Rijal, returned to Aceh from his studies in Arabia, and bitterly attacked Raniri's views and actions. As Raniri himself put it:

"Sayf al-Rijal...held debates with us over the matters which had been discussed before. We ask: 'How could you approve of the people who assert that man is Allah and Allah is man'? He answers: 'This is my belief and that of the people of Mecca and Medina.' Then his words prevail, and many people return to the wrong belief." (Raniri, Fath al-Mubin, as translated in Azra 2004: 60-61)

Aceh opinion favoured Sayf, and Raniri was forced to flee back to Gujarat in 1643. This opened the way for a new consensus personified in Aceh's most beloved sufi master, Sheikh Abdul-Rauf al-Singkili (c.1617-1684). His own copious writings never condemned either Hamzah Fansuri or Raniri, but sought a synthesis which would reconcile a commitment to shari'a with the appreciation of the inner knowledge of the mystics. It was probably he who appealed to one of his teachers in Mecca for a ruling whether it was legitimate for a sultan to have executed a sufi accused of heresy by another ulama, when the sufi in question responded that he could not repent as his argument had not been understood. He received the answer he appears to have hoped for, that such executions were very grave errors.

Although religious courts continued to function in several port-cities, there is little evidence in Aceh or elsewhere after the 1660s of the harsh application of shari'a laws as occurred earlier in the century, or of executions on religious grounds. The decline of absolutist port-rulers reduced the coercive power of the state in religious matters, and allowed religious solidarities to centre rather in the mystical tarekat (sufi orders), notably the Qadariyyah and Shatariyya. These encouraged an inner piety expressed in ecstatic chanting and rituals at the graves of the saints and founders of mysticism, particularly the great local sheikhs, Abdurrauf of Aceh and Yusuf of Makassar (Reid 2010). 
In Java the 16th century had seen much conflict between coastal and cosmopolitan Muslims and old-school Javanese. A guide to Islamic behaviour of the period, probably from Demak, warned against honouring idols, denying one's Islam or suggesting it made no difference. It condemned new Muslims who killed unbelievers only to take their property, rather than for truly religious motives (Drewes 1978: 15, 35-39). But the 17th century was a story of destroying or marginalising the cosmopolitan coastal centres of Islam, while selectively borrowing from them to create a remarkable synthesis of distinctively Javanese Islam. This became established in the warlike reign of Sultan Agung of Mataram (r. 1613-1646), who unified the Javanese-speaking area for the first and only time by conquering the coastal Muslim port-states one by one from his thenrustic base in what became Jogjakarta.

Despite the Hindu subject matter of its stories from the Mahabharata and the Ramayana, the Javanese shadow-puppet theatre (wayang kulit) appears to have developed its modern form in those urban crucibles of Islamic innovation. It may have been a cultural compromise to avoid depicting human forms in deference to Islamic prohibition, but instead their shadows. As elite patronage of Javanese performance moved to the inland capital of Mataram, the stories of Arjuna and Bima continued to enthral Javanese audiences, and to convey the deeper inner truths for which the world of Islamic legal obligation was the outer shell.

It was after the disastrous defeat of Sultan Agung's attack on Dutch Batavia in 1629 that he turned his greatest attention to creating an integrated and selfsufficient culture within his realm. He came to accept the Dutch as coastal tributaries, concerned with the international trade that provided exotic luxuries to his court but was no longer of more substantial interest. The Sultan brought to his capital the Surabaya prince and exemplary literatus, Pangeran Pekik, famous for rendering the new Muslim knowledge into elegant Javanese poetry. Agung coopted Pekik's charisma by strategic intermarriages, and gave him the task of domesticating and Javanising the most sacred centres of Muslim mysticism Ampel, Giri and Tembayat. A hybrid architectural style was developed for these sacred places, and for the royal cemetery Agung built for himself at Imogiri, giving the entrances to the holiest Muslim centres a Balinese external appearance to modern eyes. Sultan Agung also authorised a uniquely complex Javanese calendar, incorporating the Islamic cycle of weeks and lunar months into the solar Indian-derived Saka calendar. The new kingship model was to focus on symbolic assertions of the centrality of the king-priest (prabu pandita), a supernatural figure who could magically pray in Mecca every Friday, and yet control the spiritual forces of Java through his ritual couplings with the Queen of the South Seas (Ratu Kidul) and rituals to the spirits of the volcanoes. What Ricklefs (2006) 
calls the "mystic synthesis" successfully brought virtually all Javanese into the new religion, even though there were constant challenges to royal authority.

Southeast Asia is rightly celebrated for its capacity to retain diversity, in human society as in its flora and fauna. In religious terms, however, this point must be qualified by the "frontier" quality of scriptural religions. Diversity inhered in the myriad ways in which the local was combined with the universal, the highly plural spirit world with revealed scripture. Universal religion itself, however, was strangely uniform. The inherent diversity of Middle Eastern Islam, with its entrenched Sunni and Shi'a sects and its four schools of law, was exported to India but not Below the Winds. Because Islam played the role of external legitimator of local eminence, it was perceived as singular even when practiced as plural. Shi' ite rituals and texts found their way below the winds, but whenever orthodoxy became an issue for states it was purely Sunni with the Shafi'i school of law. The prominence of Arabs from Hadhramaut in mediating Middle Eastern complexities to Southeast Asia may be the key reason for this. In the long term this would hold dangers for the acceptance of diversity. Independent Indonesia officially recognised two Christianities as permissible for its citizens, but only one Islam. Only in the twenty-first century, however, did the quest for universal orthodoxy make this a problem by contrast with the very evident practical diversities of vernacularisation.

\section{Christianity}

The Christian communities developed under Portuguese auspices in Southeast Asia saw few Catholic priests after the Dutch conquered Melaka in 1641 and expelled Portuguese as the first priority from their other conquests around the Archipelago - notably the large communities in Makassar and Ambon (Maluku). Only a tiny Portuguese elite withdrew to Goa or Portugal. Most faced the choice of remaining in Dutch-controlled cities by accepting the Reformed (Calvinist) official faith of the VOC, or moving to Asian-ruled centres such as Siam, Cambodia, Burma or the south-eastern islands of the Archipelago (Lesser Sunda Islands of Flores, Solor, Timor). The best-known centre was Ayutthaya (Siam), which became a new centre for predominately French missionaries to train Asian priests for East and parts of Southeast Asia (though not the Philippines). In Siam itself, however, there were only about 2,000 Catholics in the 1660s and only a few more in the 1810s, when a more peaceful modern period of expansion began. More influential in the long term were hybrid communities known as Topaz or "black Portuguese" in Flores and Timor. From bases first in Solor, then Larantuka (Flores) and Lifao (Timor), they established local alliances that the Dutch largely ignored, partly because they were almost totally devoid of priests 
or of Portuguese officialdom. Their lay organisation, a confraria (brotherhood) devoted to Mary, retained a vernacular synthesis of Catholicism, expressed in a mix of Portuguese and commercial Malay, into the era of modern missions in the late 19 th century.

The Christians of the Philippines, too, were left much more to their own devices after the phenomenally rapid changes of the first sixty years. Fr. Schumacher (1984: 254-256) argued that the initial conversion process was perhaps the most rapid but profound to be found anywhere in Christian history, partly through the insistence that converts would not be baptised unless they agreed to a subsequent ongoing course of instruction. But from over 300 European priests in the islands in the early 1600 s, the numbers failed to rise thereafter despite their vastly extended responsibilities as the population expanded for whom they were the chief representative of both church and state. Rather than moving to the training of a Filipino clergy, the friars exchanged their missionary impetus for a relatively comfortable role as provincial elite, presiding over a calendar of festivals, marriages and funerals. Philippine piety was channelled into paths later known as "folk Catholicism", whereby an elite received some Christian education but the majority participated primarily through feasts, rituals, dramatisations and the partial Christianisation of the major rites of passage. Even the religious orders of nuns were closed to Philippine women, but they responded in their own vernacular way by establishing parallel beatarios, with the religious disciplines and piety of a sisterhood but a largely autonomous vernacular expression.

Even without a significant number of Filipino priests, the gospel was vernacularised through the extensive translation and printing, initially of Spanish religious texts in translation. But Filipino delight in oral poetry was extended to the bilingual (ladino) poetry of figures like Tomas Pinpin, who was able to publish some of his Tagalog prose and poetry because he worked in the printing house of the Dominicans in the early 1600s. Several Spanish friars were able enough to produce sacred works and dictionaries in Tagalog, Cebuano and Ilocano, but what the Filipinos loved the most were poetry and dramatisation of the Christian feasts, especially when written by their own poets. The first poetic renderings of the passion (death and resurrection) of Christ by Filipinos was published in Tagalog in 1704, from the pen of prominent Tagalog layman, Gaspar Aquino de Belem. His version was emulated, amended and enacted in parishes throughout the Philippines thenceforth, generating a vernacular idiom of the Christian experience.

An endemic power struggle between the Governor and the Archbishop of Manila, both appointed by the King of Spain, and the religious orders which 
claimed loyalty only to the Pope culminated in the 1760s. A new "enlightened despotism" in Madrid sought to control the clergy in national interests, leading to the suppression of the Jesuits throughout the empire and consequent expulsion from 130 parishes in the Visayas and Mindanao. There was a sudden need for Filipino diocesan priests answerable to the Manila Archbishop and the King, to replace European friars deemed loyal to their order and to the Pope. The result was at last to produce a Filipino clergy, though one trained so hastily that a large cultural gap emerged between them and the Spanish-trained religious orders. An English visitor wrote in the 1820 s of "a keen and deadly jealousy ... between these [Filipino priests] and the Spanish ecclesiastics, or rather a hatred on one side and a contempt on the other" (Schumacher 1979: 213). Filipinos entrusted with parishes tended to abandon the big stone structures the friars had built for their needs, in favour of living Filipino style in wood and bamboo houses, less concerned with maintaining celibacy than their Spanish colleagues, and more with their kinship networks. They were less critical of the sensuality condemned by Spaniards as keeping "these regions aflame with an infernal and inextinguishable fire" (Velarde 1749: 93-94); and of the universal belief that spirits of the dead needed to be manipulated and assuaged by the living. The healing syntheses that emerged here were made possible by Catholicising offerings and prayers for the dead, notably at funerals and the annual graveside feasting on All Saints' Day. The prominent role of Filipino clergy in generating a Filipino identity and national consciousness in the 19th century originated in this period of explicit vernacularisation.

\section{Buddhism}

Theravada Buddhism was also sustained by a celibate male clergy, but not one that was foreign-born as in the early Catholic Philippines. The key to the long 18th century in the Theravada Mainland was the gradual homogenisation of monastic rules of ordination and practice, but their separation into distinct Myanma, Thai, Lao and Khmer vernaculars. The rich and powerful monasteries sustained by royal or aristocratic endowment gave way to a more popular pattern of integration with the population. Monks received alms from ordinary villagers as well as town-dwellers and pilgrims, and in return provided not only blessings and key rituals of life and agricultural cycles, but instruction in literacy and Buddhist virtues for young boys temporarily assigned to the monkhood. Burmese monks were especially successful in this role. By 1800 they were estimated to comprise about two per cent of the Burmese population, and "there was not any village, however small", which did not have at least one monastery, where all boys at puberty were supposed to spend some time (Sangermano 1966[1833]: 90). This 
practice had produced by the 19th century more than $50 \%$ male adult literacy in the Myanma language -perhaps a record for any pre-industrial society.

The Buddhist sangha was particularly important in developing a common cultural identity among Lao and Khmer, for whom the long 18th century was a time of political fragmentation and intervention by Siam, Burma and Dai Viet. Bereft of strong kings, both societies cohered around their respectively Lao- and Khmer-speaking monkhood. Burmese and Thai monarchs in this period of consolidation also knew that alliance with the sangha was essential. The primary purpose of kingship became the promotion of the dharma, or Buddhist teaching.

Each culture area emerged with its own compromise with the older pattern of spirit worship. The kings of this period did not attack spirit worship as some had in the age of commerce, but accommodated it within the Buddhist framework. Thai kings retained Brahmins at court to enhance their supernatural power with Sivaite ritual, but popularly the Hindu deities (beloved in the Thai version of the Ramayana) were incorporated into a Buddhist pantheon. Burmese rulers went further in seeking to nationalise and unify the extraordinary diversity of the spirit world through a state cult of 37 recognised great spirits (nat), said to originate, like many traditions, with King Anawrahta of Pagan (1044-1077). Though royal rituals propitiating this pantheon may have served unifying purposes, the official cult by no means excluded local spirits, and indeed millions of other nat, some of whom were described in official cosmology and embedded in the rituals of Buddhist monks. Every village had its own guardian nat and, as in Siam, every building honoured a spirit or collection of spirits. Finally an elaborate system of omens was incorporated into the synthesis, some based on the calendar and the stars, others relating to bodily particulars. Increasingly systematised as the Burmese and Thai realms became more integrated, these syntheses of universal and vernacular served to unify culture areas according to language.

\section{Popular religion}

In my understanding, the long $16^{\text {th }}$ century brought change so profound as to justify the term revolution, but also erected barriers between the new religions and those who rejected it, the insiders and outsiders, and between men and women. The long $18^{\text {th }}$ was a time of cultural integration and synthesis between the old and the new, during which external models were much reduced. Local religious leadership became much more important, and brought with it a popularisation of the new religions to much wider circles of society. Vernacularisation seems an apt term for this, not only in the ways in which Arabic, Spanish/Latin and Pali concepts were translated into local languages, but also in the way time-honoured 
habits of dealing with death, gender relations and power found a place within the new faiths.

Both cosmopolis and vernacularisation, in other words, were necessary to create the pattern of popular religion found in $19^{\text {th }}$ century Southeast Asia, at the time new forms of cosmopolitanism began again to inject both dynamic and division into Southeast Asian religion. But that is another story.

\section{References}

Acabado, Stephen (2009): “A Bayesian approach to dating agricultural terraces: a case from the Philippines", in: Antiquity 83, pp. 801-814.

Azra, Azyumardi (2004): The Origins of Islamic Reformism in Southeast Asia: Networks of Malay-Indonesian and Middle Eastern 'Ulama' in the seventeenth and eighteenth centuries, Sydney: Allen \& Unwin.

Barros, João de (1973[1563]): Da Asia: Decada III, (Lisbon: Regia Officina, 1777, reprinted Lisbon 1973).

Bonatz, Dominik (2007): The Megaliths in Nias (http://www.nirn.org/pdf/ 070614_bonatz.pdf), last accessed 14/10/213.

Chirino, Pedro (1969[1604]): Relación de las Islas Filipinas: The Philippines in 1600, Manila: Historical Conservation Society.

Drakard, Jane (1990): A Malay Frontier: Unity and Duality in a Sumatran Kingdom, Ithaca: Cornell University Southeast Asia Program Publication.

Knaap, Gerrit (1987): Kruidnagelen en Christenen: De Verenigde Oost-Indische Compagnie en de bevolking van Ambon 1656-1696, Dordrecht: Foris for Verhandelingen van het Koninklijk Instituut voor Taal-, Land- en Volkenkunde.

La Loubère, Simon de (1969[1691]): A New Historical Relation of the Kingdom of Siam. Kuala Lumpur: Oxford University Press.

Phelan, J. L. (1959): The Hispanization of the Philippines. Spanish Aims and Filipino Responses 1565-1700, Madison: University of Wisconsin Press.

Pinto, Mendes (1989[1578]): The Travels of Mendes Pinto, Chicago/London: University Of Chicago Press.

Pollock, Sheldon (2006): The Language of the Gods in the World of Men: Sanskrit, Culture, and Power in Premodern India, Berkeley: University of California Press.

Raniri, Nuru'd-din ar- (1966[1643]): Bustanu's-Salatin, Bab II, Fasal 13, ed. T. Iskandar (Kuala Lumpur, Dewan Bahasa dan Pustaka). 
Reid, Anthony (1988): Southeast Asia in the Age of Commerce. Vol I: The Lands below the Winds, New Haven: Yale University Press.

Reid, Anthony (1993): Southeast Asia in the Age of Commerce. Vol II: Expansion and Crisis, New Haven: Yale University Press.

Reid, Anthony (1997): The Last Stand of Asian Autonomies: Responses to Modernity in the Diverse States of Southeast Asia and Korea, 1750-1900, Basingstoke: Macmillan.

Reid, Anthony (2010): "Islam in Southeast Asia and the Indian Ocean Littoral, 1500-1800: Expansion, Polarization, Synthesis", in: David Morgan and Anthony Reid (eds.), The New Cambridge History of Islam, Vol. 3: The Eastern Islamic World, Eleventh to Eighteenth Centuries, Cambridge: Cambridge University Press, pp. 427-469.

Ricci, Ronit (2011): Islam Translated: Literature, Conversion, and the Arabic Cosmopolis of South and Southeast Asia, Chicago: University of Chicago Press.

Ricklefs, Merle C. (1979): "Six centuries of Islamization in Java", in: Nehemia Levtzion (ed.), Conversion to Islam, New York: Holmes and Meier, pp. 100128.

Ricklefs, Merle C. (2006): Mystic Synthesis in Java: A history of Islamization from the fourteenth to the early nineteenth centuries, Norwalk: Eastbridge.

Sangermano (1966[1833]): A Description of the Burmese Empire, London: Susil Gupta.

Schumacher, Frank, S.J. (1979): Readings in Philippine Church History, Quezon City: Loyola School of Theology, Ateneo de Manila University.

Schumacher, Frank, S.J. (1984): "Syncretism in Philippine Catholicism: Its Historical Causes", in Philippine Studies 32, pp. 251-72.

Scott, James (2009): The Art of Not Being Governed: An Anarchist History of Upland Southeast Asia, New Haven: Yale University Press.

Velarde, Pedro Murillo (1909[1749]): "Historia de Philipinas 1493-1803", translated in E.H. Blair and J.A. Robertson, The Philippine Islands, Vol 44, Cleveland: Arthur Clark, pp. 27-119.

Waterson, Roxana (1997): “The Contested Landscapes of Myth and History in Tana Toraja", in: James Fox (ed.), The Poetic Power of Place: Comparative Perspectives on Austronesian Ideas of Locality, Canberra: ANU E Press, pp. 63-88.

Wheeler, Charles (2006): "One region, Two Histories: Cham Precedents in the History of the Hoi An Region", in: Nhung Tuyet Tran/Anthony Reid (eds.), Viet Nam: Borderless Histories, Madison: University of Wisconsin Press, pp.163-93. 
Zaide, Gregoria F. (1990): Documentary Sources of Philippine History, Vol.I, Metro Manila: National Book Store. 